\title{
ANALYSIS OF THE SECONDARY CURVES IN PATIENTS UNDERGOING SELECTIVE ARTHRODESIS LENKE I
}

\author{
ANÁLISE DAS CURVAS SECUNDÁRIAS EM PACIENTES SUBMETIDOS A \\ ARTRODESE SELETIVA LENKE I \\ ANÁLISIS DE LAS CURVAS SECUNDARIAS EN PACIENTES SOMETIDOS A \\ ARTRODESIS SELECTIVA LENKE I
}

Tadeu Gervazoni Debom¹, Charbel Jacob Júnior¹, Igor Cardoso Machado ${ }^{1}$, José Lucas Batista Júnior¹, Marcos Alexandre Novo Brazolino",

Thiago Cardoso Maia', Lucas Siegle do Nascimento², Tiago Costa Vieira²

\begin{abstract}
Objective: To radiographically evaluate the behavior of the secondary curves in the coronal and sagittal planes in patients with AIS classified as Lenke I, who underwent surgical treatment of selective arthrodesis by posterior approach. Methods: Retrospective study which analyzed 40 patients with AIS, being 33 female. The measurement of the radiographic parameters used followed the recommendations by Cobb. Results: The average correction of the thoracic proximal, primary and lumbar curves was 34.73\%, 75.06\% and 64.64\%, respectively. Conclusion: Surgical treatment by selective arthrodesis in cases of AIS Lenke type I provide correction of compensatory curves in the coronal and maintenance in the sagittal plane.
\end{abstract}

Keywords: Arthrodesis; Scoliosis; Adolescent.

\section{RESUMO}

Objetivo: Avaliar radiograficamente o comportamento das curvas secundárias nos planos coronal e sagital em pacientes portadores de EIA classificados como Lenke I, que foram submetidos a tratamento cirúrgico de artrodese seletiva por via posterior. Métodos: Estudo retrospectivo no qual foram analisados 40 pacientes portadores de EIA, sendo 33 do sexo feminino. A mensuração dos parâmetros radiográficos utilizados seguiu o preconizado por Cobb. Resultados: A média de correção das curvas torácicas proximal, principal e lombar foi de 34,73\%, 75,06\% e 64,64\% respectivamente. Conclusão: O tratamento cirúrgico por artrodese seletiva em casos de ElA Lenke tipo I proporciona correção das curvas compensatórias no plano coronal e manutenção do plano sagital.

Descritores: Artrodese; Escoliose; Adolescente.

\section{RESUMEN}

Objetivo: Evaluar radiográficamente el comportamiento de las curvas secundarias en el plano coronal y sagital en pacientes con EIA clasificados como Lenke I, que se sometieron a tratamiento quirúrgico selectivo por artrodesis por vía posterior. Métodos: Estudio retrospectivo, que analizaron a 40 pacientes con EIA, siendo 33 del sexo femenino. La medición de los parámetros radiológicos utilizados siguió las recomendaciones de Cobb. Resultados: La corrección media de las curvas torácica proximal, principal y lumbar fue 34,73\%, 75,06\% y $64,64 \%$, respectivamente. Conclusión: El tratamiento quirúrgico mediante artrodesis selectiva de los casos de EIA Lenke tipo I proporciona la corrección de las curvas de compensación en el plano coronal y el mantenimiento en el plano sagital.

Descriptores: Artrodesis; Escoliosis; Adolescente.

\section{INTRODUCTION}

Adolescent idiopathic scoliosis is the most common form of spinal deformity. It is defined as a deformity of more than $10^{\circ}$ in the coronal plane, associated with rotation of the vertebrae and costotransverse joints, and with no defined etiology. ${ }^{1-3}$ Several theories have been studied, such as changes in collagen, hormonal changes, and more recently, genetic changes, ${ }^{4}$ but we still do not have a complete definition of its origin.

The treatment for this type of deformity depends on the degree and the location of the curve, and is based on the degree of potential growth of the patient. ${ }^{5}$ In curves greater than $45^{\circ}$, measured using the Cobb method, surgery is indicated in patients with growth potential. ${ }^{6}$ The goals of surgical treatment are to correct the curve, to recover balance in the coronal and sagittal planes, to prevent progression and possible cardiopulmonary complications, and consequently, to provide esthetic improvement.

Several classification systems have been proposed which, depending on the type of deformity, can be used to define the type of proposed treatment. The classification of Lenke et al. ${ }^{7,8}$ examines not only deformities in the coronal plane, as suggested by King et al., ${ }^{9}$ but also the secondary curves and sagittal balance, since changes in these measurements can directly impact the surgical decision.

The Lenke classification brought great advances to the interpretation of deformities because it clearly defined what would be the main curve, a secondary proximal curve, a secondary distal curve, and the relevant sagittal modifiers, ${ }^{7,8}$ criteria that were previously poorly standardized in the literature. Following this standardization, 
there was a significant increase in publications using the Lenke classification. $^{7,8}$

In curves classified as Lenke I, studies show that selective arthrodesis is the appropriate treatment for this type of pathology, as it enables correction of the compensatory curves by performing an arthrodesis involving fewer segments, benefiting the patient. ${ }^{10,11}$

The objective of this study is to evaluate the behavior of the secondary curves radiographically, both in the coronal and the sagittal planes, by assessing the pre- and postoperative exams of patients with adolescent idiopathic scoliosis classified as Lenke I submitted to posterior approach selective arthrodesis surgery.

\section{CASE SERIES AND METHODS}

A retrospective study, conducted following approval of the Institutional Review Board (IRB) - Santa Casa de Misericórdia de Vitória (12041313.0.0000.5065), in which 40 patients with AIS classified as Lenke I were analyzed; 33 female, with an average age of 14.7 years, ranging from a minimum of 11 to a maximum of 22 years of age.

The inclusion criteria were: patients with AIS classified as Lenke type I, between 10 and 22 years of age, indicated for surgery due to spinal deformity, and in follow up at Hospital Santa Casa de Misericórdia.

The exclusion criteria were patients who did not agree to sign the Informed Consent Form, those who did not have the pre-established radiographs taken, and those who refused surgical treatment.

The radiographic parameters used for this study were measured following the recommendations of Cobb, ${ }^{12}$ for which panoramic radiographs are taken of the spine in the orthostatic position, in the pre- and immediate postoperative periods and after 4 weeks. ${ }^{13}$ (Figure 1)

The compensatory curves were also measured using the Cobb method $^{12}$ as the standard in panoramic pre- and postoperative radiographs of the spine in the orthostatic position, as described.

A descriptive analysis was used to describe or summarize the sample of children and adolescents with scoliosis.

The Student's t test was used to compare the preoperative and postoperative evaluations. A level of significance of $5 \%$ was adopted, and a confidence interval of $95 \%$. The statistical program used in the analyses was IBM's SPSS Statistics version 21.

\section{RESULTS}

The sample was composed of 40 patients who met the inclusion criteria of the study. We compared the pre- and postoperative spinal radiographs of adolescents and young adults between the ages of 11 and 22 years old with AIS with Lenke type I curves with indication for surgery, and who had no other vertebral deformities.

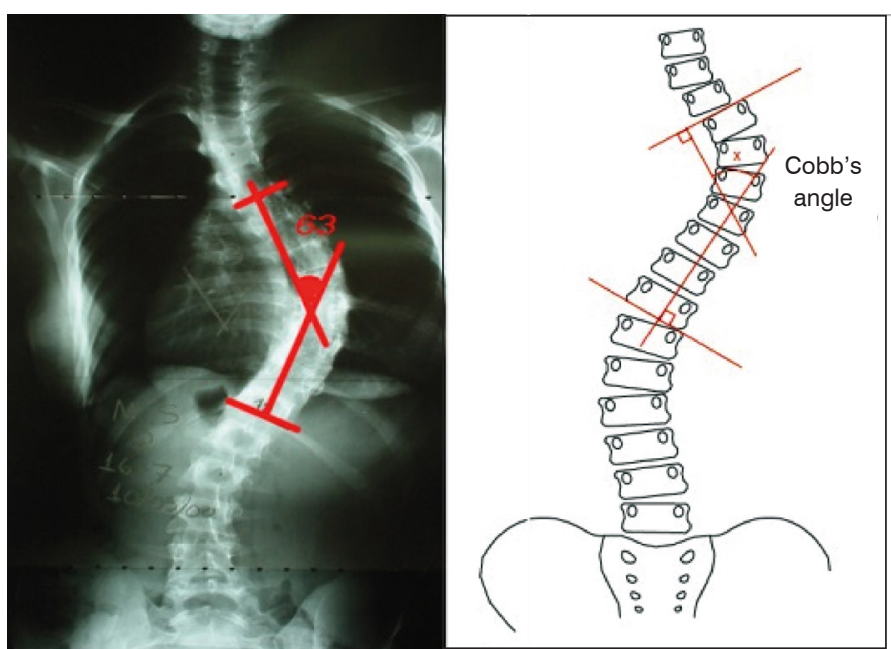

Figure 1. Cobb method for measuring the principal and secondary curves.
The averages of the Cobb index in the anteroposterior preoperative radiographic exam were $29.97^{\circ}$ for the proximal thoracic curve, $59.08^{\circ}$ for the principal thoracic curve, and $35.26^{\circ}$ for the lumbar curve. The average postoperative measurements were $19.56^{\circ}$, $14.73^{\circ}$, and $12.5^{\circ}$ respectively, with corrections percentages of $34.73 \%, 75.06 \%$, and $64.64 \%$ for their respective curves, as shown in Table 1.

Table 1. Comparative analysis between the curves pre- and postoperatively.

\begin{tabular}{c|c|c|c}
\hline $\begin{array}{c}\text { Averages - AP } \\
\text { radiographs }\end{array}$ & $\begin{array}{c}\text { Proximal } \\
\text { Thoracic }\end{array}$ & $\begin{array}{c}\text { Principal } \\
\text { Thoracic }\end{array}$ & Thoracolumbar \\
\hline Preoperative & $29.97^{\circ}$ & $59.08^{\circ}$ & $35.26^{\circ}$ \\
\hline Postoperative & $19.56^{\circ}$ & $14.73^{\circ}$ & $12.5^{\circ \circ}$ \\
\hline $\begin{array}{c}\text { Percentage of } \\
\text { postoperative correction }\end{array}$ & $34.73 \%$ & $75.06 \%$ & $64.64 \%$ \\
\hline
\end{tabular}

Table 2 shows the analysis of the cervical, thoracic, thoracolumbar, and lumbar profiles in the pre- and postoperative periods.

Table 2. Analysis of the pre- and post-operative profiles.

\begin{tabular}{c|c|c|c}
\hline Averages & Thoracic profile & $\begin{array}{c}\text { Thoracolumbar } \\
\text { profile }\end{array}$ & Lumbar profile \\
\hline Preoperative & $27.41^{\circ}$ & $8.37^{\circ}$ & $45.72^{\circ}$ \\
\hline Postoperative & $25.44^{\circ}$ & $4.88^{\circ}$ & $38.94^{\circ}$ \\
\hline Improvement & $2.1^{\circ}$ & $3.6^{\circ}$ & $6.5^{\circ}$ \\
\hline
\end{tabular}

\section{Statistical Analysis}

The Student's t test for paired samples was used to compare the preoperative and postoperative evaluations through the differences in the averages of the degrees. (Table 3)

Table 3. Comparison between preoperative and postoperative by the Student's t test.

\begin{tabular}{|c|c|c|c|c|c|}
\hline & \multicolumn{4}{|c|}{ Paired differences } & \multirow{3}{*}{$P$ value } \\
\hline & \multirow[t]{2}{*}{ Average } & \multirow{2}{*}{$\begin{array}{c}\text { Stan- } \\
\text { dard } \\
\text { devia- } \\
\text { tion }\end{array}$} & \multicolumn{2}{|c|}{\begin{tabular}{|c|} 
Confidence in- \\
terval of $95 \%$ of \\
the difference
\end{tabular}} & \\
\hline & & & Lower & Upper & \\
\hline $\begin{array}{c}\text { Proximal thoracic - proximal } \\
\text { thoracic correction }\end{array}$ & 16.824 & 16.601 & 11.031 & 22.616 & $<0.001$ \\
\hline $\begin{array}{c}\text { Thoracic - thoracic } \\
\text { correction }\end{array}$ & 32.829 & 10.211 & 29.321 & 36.336 & $<0.001$ \\
\hline Lumbar - lumbar correction & 17.722 & 12.377 & 13.535 & 21.910 & $<0.001$ \\
\hline $\begin{array}{c}\text { Proximal thoracic - } \\
\text { postoperative proximal } \\
\text { thoracic }\end{array}$ & 10.030 & 41.359 & -4.635 & 24.696 & $<0.001$ \\
\hline $\begin{array}{c}\text { Thoracic - postoperative } \\
\text { thoracic }\end{array}$ & 43.974 & 9.925 & 40.757 & 47.192 & $<0.001$ \\
\hline $\begin{array}{c}\text { Lumbar - postoperative } \\
\text { lumbar }\end{array}$ & 23.176 & 11.666 & 19.106 & 27.247 & $<0.001$ \\
\hline $\begin{array}{c}\text { Cervical profile - postopera- } \\
\text { tive cervical profile }\end{array}$ & -4.000 & 14.111 & -9.004 & 1.004 & 0.011 \\
\hline $\begin{array}{c}\text { Thoracic profile - postopera- } \\
\text { tive thoracic profile }\end{array}$ & 2.588 & 12.415 & -1.744 & 6.920 & 0.233 \\
\hline $\begin{array}{c}\text { Thoracolumbar profile - } \\
\text { postoperative thoracolumbar } \\
\text { profile }\end{array}$ & 2.794 & 7.248 & 0.265 & 5.323 & 0.031 \\
\hline $\begin{array}{c}\text { Lumbar profile- } \\
\text { postoperative lumbar profile }\end{array}$ & 7.882 & 10.020 & 4.386 & 11.379 & $<0.001$ \\
\hline
\end{tabular}




\section{DISCUSSION}

The goal of surgical treatment of AIS is to correct deformity in the coronal and sagittal planes, through arthrodesis of the lowest number of segments possible, in order to avoid possible complications such as degenerative disease of the non-fused segments, principally in the lumbar region. ${ }^{14-17}$ Applying the concept of selective arthrodesis permits us to control and partially correct the main thoracic curve, and to maintain the mobility of the segments, particularly in the lumbar segments.

Lenke et al ${ }^{18}$ demonstrated that after selective arthrodesis surgery, the correction of the compensatory lumbar curve is spontaneous and consistent. In a study published by Ritzman et al., ${ }^{19}$ a correction of $49 \%$ was achieved. Sun et al. ${ }^{20}$ conducted a study with 43 patients with adolescent idiopathic scoliosis submitted to selective posterior arthrodesis, and concluded that the restoration of coronal balance was compensated mainly by the non-fused distal segments.

Wong et al. ${ }^{21}$ reported shorter surgical time in patients submitted to posterior selective arthrodesis and consequently a lower risk of complications. The study published by Fisher and $\mathrm{Kim}^{22}$ shows that selective arthrodesis in AIS is a way to correct the curve, recover balance, and maintain flexibility by leaving a higher number of segments free. Yu et al. ${ }^{23}$ state that this type of treatment is effective and safe, maintaining good balance in the coronal and sagittal planes.

In this study, selective arthrodesis of the principal thoracic curve resulted in a correction of $75 \%$, while for the secondary curves, though not directly targeted in the surgery, significant correction was obtained, with $34.73 \%$ correction in the proximal thoracic curve and $64.64 \%$ in the lumbar curve. The thoracolumbar profile showed a reduction of $41 \%$ in the average angle in the sagittal plane, while the thoracic and lumbar profiles showed reductions of 7.7 and $14.1 \%$, respectively.

\section{CONCLUSION}

Surgical treatment of Lenke type I AIS by means of selective arthrodesis provides correction of the compensatory curves in the coronal plane and maintenance of the sagittal plane.

All authors declare no potential conflict of interest concerning this article.

\section{REFERENCES}

1. de Baat P, van Biezen EC, de Baat C. Scoliosis: review of types, aetiology, diagnostics, and treatment 1. Ned Tijdschr Tandheelkd. 2012;119(10):474-8.

2. Ahn UM, Ahn NU, Nallamshetty L, Buchowski JM, Rose PS, Miller NH, et al. The etiology of adolescent idiopathic scoliosis. Am J Orthop (Belle Mead NJ). 2002;31(7):387-95.

3. Altaf F, Gibson A, Dannawi $Z$, Noordeen H. Adolescent idiopathic scoliosis. BMJ. 2013;346:f2508

4. Wang S, Qiu Y, Ma Z, Xia C, Zhu F, Zhu Z. Expression of Runx2 and type X collagen in vertebral growth plate of patients with adolescent idiopathic scoliosis. Connect Tissue Res. 2010;51(3):188-96

5. Moe JH, Byrd JA. Idiopathic scoliosis. In: Lonsteins JE, Winter RB, Bradford DS, Olgivie JW, editors. Moe's textbook of scoliosis and other spinal deformities. 2nd ed. Philadelphia: Saunders; 1987. p.191-232.

6. Petit $\mathrm{Y}$, Aubin $\mathrm{CE}$, Labelle $\mathrm{H}$. Three-dimensional imaging for the surgical treatment of idiopathic scoliosis in adolescents. Can J Surg. 2002;45(6):453-8.

7. Liljenqvist U, Lerner T, Bullmann V. Selective fusion of idiopathic scoliosis with respect to the Lenke classification. Orthopade. 2009;38(2):189-92.

8. Lenke LG. Lenke classification system of adolescent idiopathic scoliosis: treatment recommendations. Instr Course Lect. 2005;54:537-42.

9. King HA, Moe JH, Bradford DS, Winter RB. The selection of fusion levels in thoracic idiopathic scoliosis. J Bone Joint Surg Am. 1983;65(9):1302-13.

10. Janicki JA, Alman B. Scoliosis: Review of diagnosis and treatment. Paediatr Child Health. 2007:12(9):771-6.

11. Vialle R. Orthopedic and surgical treatment of idiopathic scoliosis in childhood and adolescence. Rev Prat. 2006;56(2):147-56.

12. Cobb JR. Outline for the study of scoliosis. Instr Course Lect. 1948;5:261-75.

13. Negrini S, Aulisa AG, Aulisa L, Circo AB, de Mauroy JC, Durmala J, et al. 2011 SOSORT guidelines: Orthopaedic and Rehabilitation treatment of idiopathic scoliosis during growth. Scoliosis. 2012;7(1):3.
14. Chang KW, Chang KI, Wu CM. Enhanced capacity for spontaneous correction of lumbar curve in the treatment of major thoracic-compensatory $\mathrm{C}$ modifier lumbar curve pattern in idiopathic scoliosis. Spine (Phila Pa 1976). 2007;32(26):3020-9. P

15. Dobbs MB, Lenke LG, Walton T, Peelle M, Della Rocca G, Steger-May K, et al. Can we predict the ultimate lumbar curve in adolescent idiopathic scoliosis patients undergoing a selective fusion with undercorrection of the thoracic curve? Spine (Phila Pa 1976). 2004;29(3):277-85.

16. Lenke LG, Bridwell KH, Baldus C, Blanke K. Preventing decompensation in King type II curves treated with Cotrel-Dubousset instrumentation. Strict guidelines for selective thoracic fusion. Spine (Phila Pa 1976). 1992;17(Suppl 8):S274-81

17. Lenke LG, Edwards CC 2nd, Bridwell KH. The Lenke classification of adolescent idiopathic scoliosis: how it organizes curve patterns as a template to perform selective fusions of the spine. Spine (Phila Pa 1976). 2003;28(20):S199-207.

18. Lenke LG, Betz RR, Bridwell KH, Harms J, Clements DH, Lowe TG. Spontaneous lumbar curve coronal correction after selective anterior or posterior thoracic fusion in adolescent idiopathic scoliosis. Spine (Phila Pa 1976). 1999;24(16):1663-71.

19. Ritzman TF, Upasani WV, Bastrom TP, Betz RR, Lonner BS, Newton PO. Compariso of compensatory curve spontaneous derotation after selective thoracic or lumbar fusions in adolescent idiopathic scoliosis. Spine (Phila Pa 1976). 2008;33(24):2643-7.

20. Sun Z, Qiu G, Zhao Y, Guo S, Wang Y, Zhang J, et al. The effect of unfused segments in coronal balance reconstitution after posterior selective thoracolumbar/lumbar fusion in adolescent idiopathic scoliosis. Spine (Phila Pa 1976). 2014;39(24):2042-8.

21. Wong HK, Hee HT, Yu Z, Wong D. Results of thoracoscopic instrumented fusion versus conventional posterior instrumented fusion in adolescent idiopathic scoliosis undergoing selective thoracic fusion. Spine (Phila Pa 1976). 2004;29(18):2031-8.

22. Fischer CR, Kim Y. Selective fusion for adolescent idiopathic scoliosis: a review of current operative strategy. Eur Spine J. 2011;20(7):1048-57.

23. Yu B, Zhang JG, Qiu GX, Wang YP, Weng XS. Posterior selective thoracic fusion in adolescent idiopathic scoliosis. Chin Med Sci J. 2004;19(3):216-20. 